\title{
Impact of Agricultural Land Use on Soil Organic Carbon Sequestration at Sub-catchment Scale
}

\author{
D.D.A.E. Hemamali ${ }^{1}$, U.W.A. Vitharana ${ }^{2}$, B.L.W.K. Balasooriya ${ }^{3}$, C.P. Attanayake ${ }^{2}$, W.S. Dandeniya ${ }^{2}$ \\ and S.I. Nimanthi ${ }^{2}$ \\ ${ }_{1}^{1}$ Postgraduate Institute of Agriculture, University of Peradeniya, Peradeniya, Sri Lanka \\ ${ }^{2}$ Department of Soil Science, Faculty of Agriculture, University of Peradeniya, Peradeniya, Sri Lanka \\ ${ }^{3}$ Department of Biotechnology, Faculty of Agriculture and Plantation Management, Wayamba University of Sri Lanka, \\ Kuliyapitiya, Sri Lanka
}

\section{ARTICLE INFO}

\section{Article history:}

Received: 22 July 2019

Accepted: 28 October 2019

Available online: 1 December 2019

\section{Keywords:}

Agriculture land use

Carbon sequestration

Forest

Soil organic carbon

\section{Citation:}

Hemamali, D.D.A.E., Vitharana, U.W.A., Balasooriya, B.L.W.K., Attanayake, C.P., Dandeniya, W.S. and Nimanthi, S.I. (2020) Impact of Agricultural Land Use on Soil Organic Carbon Sequestration at Subcatchment Scale. Tropical Agricultural Research, 31(1): 13-20.

DOI: http://doi.org/10.4038/tar.v31i1.8340

Vitharana, U.W.A.

https://orcid.org/0000-0002-9427-7902

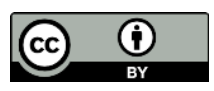

\section{ABSTRACT}

Soil organic carbon (SOC) pool determines the potential of soil to perform ecosystem services and maintain climatic stability. Land use plays a significant role in determining the carbon (C) sequestration in soil. This study aimed to determine the impact of long-term agricultural land uses on SOC and other physico-chemical properties and to determine interrelationships between SOC stock and topographic variables at sub-catchment scale in upcountry of Sri Lanka. Soil samples were collected from surface (0$30 \mathrm{~cm})$ and subsurface $(30-60 \mathrm{~cm})$ at 109 locations from vegetable $(n=42)$, tea $(n=44)$ and forest $(n=23)$ land uses in a sub-catchment (360 ha) in Nuwara Eliya. Average SOC in different land uses were compared by analysis of variance followed by Tukey post-hoc mean comparison. The largest surface SOC stock was observed in forested area $(71.8 \mathrm{Mg} / \mathrm{ha})$ followed by vegetable lands $(61.8$ $\mathrm{Mg} / \mathrm{ha}$ ) and it was significantly lesser in tea lands (50.7 $\mathrm{Mg} / \mathrm{ha}$ ). The forest soils showed the largest subsurface SOC stock (67.1 t/ha) as well, followed by tea (64.8 Mg/ha) and vegetable $(57.9 \mathrm{Mg} / \mathrm{ha})$ land uses. No significant relationship was observed between SOC stock and topographic variables, namely elevation, slope, wetness index and stream power index. This study concludes that the land use is a key determinant of the spatial heterogeneity of SOC and forest have the greater ability of sequestering $C$ compared to vegetable and tea land uses in the studied sub-catchment area.

*Corresponding author: uvithara@gmail.com 


\section{INTRODUCTION}

Soils are the largest global terrestrial pools of organic $\mathrm{C}$ which stores about two times the carbon stored in above-ground biomass (Batjes and Sombroek, 1997). Soil organic carbon has received worldwide attention due to the important role played in the global $\mathrm{C}$ cycle and its potential feedbacks on the global warming. Carbon sequestration that describes the process of capturing and long-term storage of atmospheric carbon dioxide helps to mitigate global warming and avoid climate change.

The "4 per mille" is a global concept which intends to increase the soil organic matter and carbon sequestration through agricultural practices (Minasny et al., 2017). Therefore, estimation of the spatial patterns and stocks of SOC is essential for understanding the potential of soils to sequester $\mathrm{C}$, and for quantifying the capacity of soils to serve as a SOC sink or source in changing environments (Mulat et al., 2018).

Anthropogenic interferences can alter the carbon cycle causing negative feedbacks on SOC stock. It is believed that land use change is the second main cause of carbon emission after fuel consumption (Watson et al., 2000).

The land use change and subsequent management are considered as key activities those alter the potential of soils to sequestrate C. However, the impact of agricultural land use on SOC sequestration have rarely been investigated in Sri Lanka. Yet, quantitative information of land use impacts on SOC sequestration is essential for making accurate spatial estimates of SOC stocks. Therefore, the present study was conducted to explore the changes of SOC stocks under long-term agricultural land uses compared to forest land to determine the interrelationships between SOC stock and topographic variables at subcatchment scale in upcountry of Sri Lanka.

\section{MATERIALS AND METHODS}

\section{Study area and site description}

The study was carried out in a sub-catchment which comprised of agricultural lands and forest area in Seetha Eliya in the Wet Zone of Sri Lanka (central coordinates 6 $56^{\prime} 13.87 " \mathrm{~N}$, $\left.80^{\circ} 47^{\prime} 32.41 " \mathrm{E}\right)$. Contour digital maps (1:10000) purchased from the survey department were interpolated using local kriging interpolation technique to construct a Digital Elevation Model (DEM) of the study area. The procedure developed by Jenson and Dominique (1988) was used to delineate the sub-catchment area (Figure 1). The study area receives a mean annual rainfall of about 2500 $\mathrm{mm}$ and soil in this area belongs to the Red Yellow Podzolic great soil group which falls under the soil order Ultisols and sub order Udults according to soil taxonomy. Nuwara Eliya series is the dominant soil series found in this area (Mapa et al., 2009).

\section{Soil sampling and laboratory analysis}

Conditioned Latin hypercube sampling approach was used to pick 109 samples within the sub-catchment area. These soil samples were taken at 42, 44 and 23 locations in the vegetable (90 ha), tea (120 ha) and forest (140 ha) land uses, respectively. This sampling approach was use to select samples location while representing the spatial variability of potential covariates namely elevation, slope and land use (Figure 1). A portable GPS receiver (GarminOREGON 650) was used to navigate the sampling locations. Soil samples were collected representing the surface $0-30$ $\mathrm{cm})$ and subsurface $(30-60 \mathrm{~cm})$ soils at each location. Disturbed soil samples were collected at each depth using the gauge auger and the core sampler was used to obtain undisturbed soil core samples. Air dried samples were sieved using a $2 \mathrm{~mm}$ sieve to obtain the fine earth fraction. Then, a subsample of the fine earth fraction was ground using a mortar and pestle to obtain a powdered sample (particle diameter 
$<0.125 \mathrm{~mm}$ ). Total organic carbon contents of powdered samples were determined using the modified Walkley and Black method (Nelson and Sommer, 1996). The fine earth fraction was used to determine the $\mathrm{pH}$ (1:2.5 soil to water suspension) and soil texture was determined using the pipette method (Gee and Or, 2002). Undisturbed samples were also taken with a core sampler for bulk density determination.

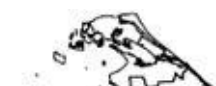

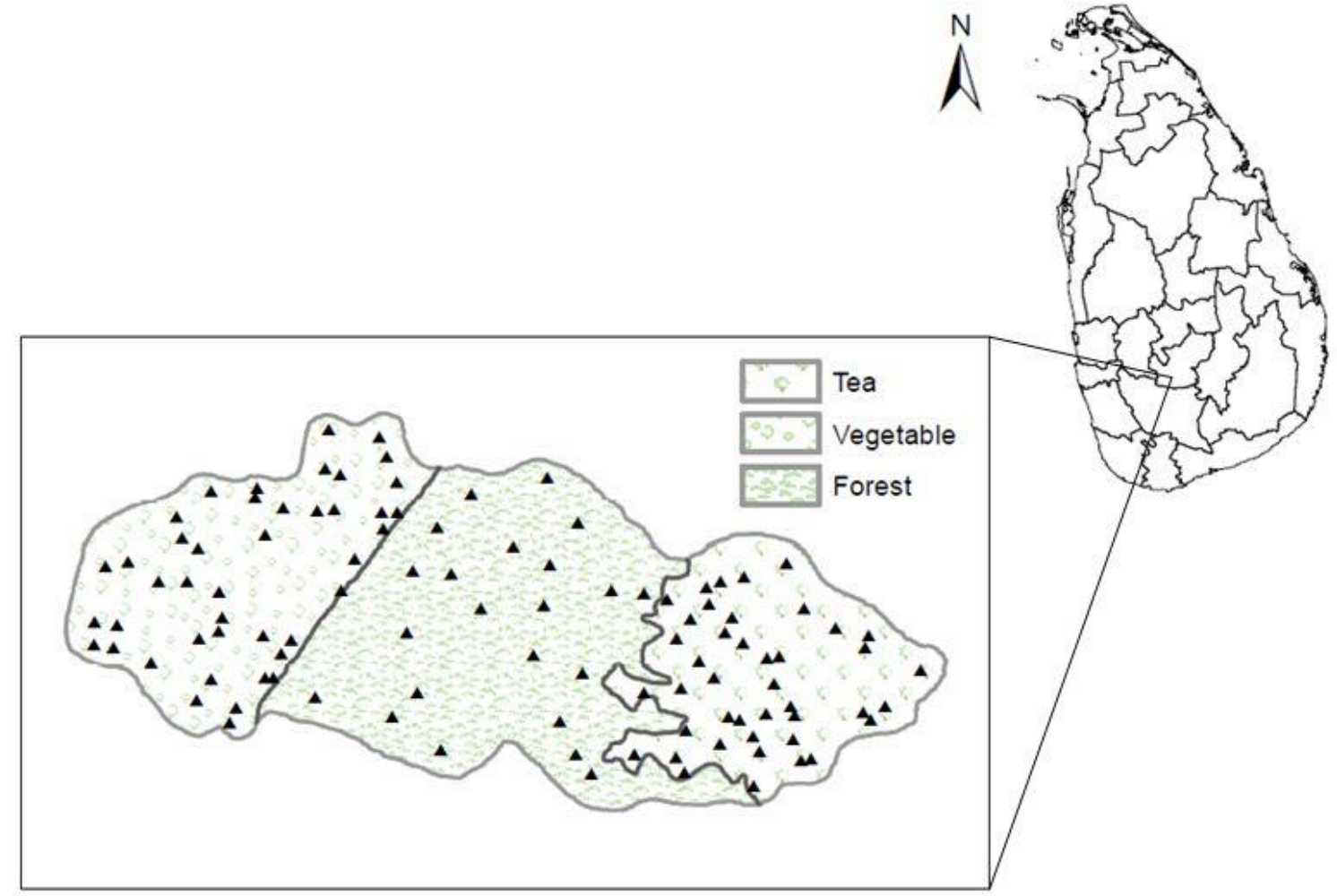

Figure 1. Locations and distribution of the sampling points (triangles) within the study area

Calculation of bulk density, SOC stock and topographic attributes

The bulk density $\left(\rho_{b}, \mathrm{Mg} / \mathrm{m}^{3}\right)$ and the SOC stock (SOCS, Mg/ha), stream power index (SPI) and wetness (WI) of a depth interval was computed using the following equations.

$$
\begin{gathered}
\rho_{b}=\frac{W 1}{\mathrm{~A}} \\
\text { SOCS }=\rho_{b} \times \mathrm{C} \times \mathrm{T} \times 100
\end{gathered}
$$

where, oven-dried mass of the core soil sample and its volume are given by $\mathrm{W} 1 \mathrm{(Mg}$ ) and $\mathrm{A}$ $\left(\mathrm{m}^{3}\right)$ respectively. The thickness of the soil layer $(\mathrm{m})$ and the percentage of organic carbon are given by $\mathrm{T}$ and $\mathrm{C}$, respectively.
The wetness index reflects the tendency of surface flow water to accumulate at any point in catchment (Moore et al., 1988). It is defined as a ratio between the slope gradient in degrees $(S l)$ and specific catchment area $\left(\mathrm{A}_{\mathrm{s}}\right)$.

$$
\mathrm{WI}=\ln \left(\frac{\mathrm{A}_{\mathrm{s}}}{\tan S l}\right)
$$

The stream power index is a measure of the erosive power of flowing water and calculated as (Wilson and Gallant, 2000);

$$
\mathrm{SPI}=A_{s} \tan S l
$$

where $S l$ is measured in degrees.

Digital elevation model was used to obtain elevation values at sample locations. Further DEM was used to generate the slope map of the 
area by using the method developed by Wilson and Gallant (2000). ArcGIS 10.3 was used for topographic analysis.

\section{Statistical analysis}

All statistical calculations were performed with SPSS 20.0 software (SPSS Inc., USA), indicating the relationship between SOC stocks and topographic factors. The data were statistically analyzed by one-way analysis of variance (ANOVA), by considering the sampling sites as replicates (random effects) within a land use and land uses as treatments (fixed effects). The mean separation of the land uses was evaluated by Tukey's post hoc test at $95 \%$ confidence interval.

\section{RESULTS AND DISCUSSIONS}

\section{Effect of land use on soil physical and chemical properties}

Table 1 shows summary statistics of measured properties in surface and subsurface soil in three land uses.

Table 1. Physical and chemical properties in different land uses in surface and subsurface soil

\begin{tabular}{lcccc}
\hline Properties & Depth & Forest $(n=23)$ & Vegetable $(n=42)$ & Tea $(n=44)$ \\
\hline $\boldsymbol{\rho}_{\boldsymbol{b}}\left(\mathrm{Mg} / \mathrm{m}^{3}\right)$ & $0-30 \mathrm{~cm}$ & $1.00^{\mathrm{a}}$ & $1.01^{\mathrm{a}}$ & $0.97^{\mathrm{a}}$ \\
& $30-60 \mathrm{~cm}$ & $1.02^{\mathrm{b}}$ & $1.12^{\mathrm{a}}$ & $1.01^{\mathrm{b}}$ \\
$\mathrm{pH}$ & $0-30 \mathrm{~cm}$ & $4.29^{\mathrm{b}}$ & $5.46^{\mathrm{a}}$ & $4.46^{\mathrm{b}}$ \\
& $30-60 \mathrm{~cm}$ & $4.42^{\mathrm{b}}$ & $5.03^{\mathrm{a}}$ & $4.25^{\mathrm{b}}$ \\
Clay\% & $0-30 \mathrm{~cm}$ & $43.2^{\mathrm{b}}$ & $26.9^{\mathrm{a}}$ & $40.7^{\mathrm{b}}$ \\
& $30-60 \mathrm{~cm}$ & $41.4^{\mathrm{b}}$ & $23.8^{\mathrm{a}}$ & $40.1^{\mathrm{b}}$ \\
Sand\% & $0-30 \mathrm{~cm}$ & $41.6^{\mathrm{b}}$ & $50.6^{\mathrm{a}}$ & $40.6^{\mathrm{b}}$ \\
& $30-60 \mathrm{~cm}$ & $42.2^{\mathrm{b}}$ & $48.9^{\mathrm{a}}$ & $41.4^{\mathrm{b}}$ \\
SOC \% & $0-30 \mathrm{~cm}$ & $2.4^{\mathrm{a}}$ & $2.1^{\mathrm{ab}}$ & $1.7^{\mathrm{b}}$ \\
& $30-60 \mathrm{~cm}$ & $2.3^{\mathrm{a}}$ & $1.8^{\mathrm{b}}$ & $2.2^{\mathrm{a}}$ \\
\hline
\end{tabular}

Mean values for each property within the raw followed by different letters are significantly different from each other at $p<0.05$. $n=$ No of samples

Bulk density $\left(\rho_{b}\right)$ of surface soil did not show significant differences across land uses. However, $\rho_{b}$ of the subsurface was significantly high in vegetable lands than the other two land uses, which could be resulted due to the frequent ploughing and compactions. The $\mathrm{pH}$ values observed in the study area were within the ranges (4.29-5.46) of acidic in reaction. Forest and vegetable lands showed similar surface and subsurface $\mathrm{pH}$ values. However, significantly higher soil $\mathrm{pH}$ was observed in both surface (5.46) and subsurface (5.03) soils in vegetable lands which could be due to the neutralization resulted through liming materials applied by farmers.

Significantly lower clay content was observed in vegetable land in comparison to tea and forest land uses. Several studies have indicated that the severe soil erosion occurs in vegetable cultivated areas in wet zone (Jayasekara et al., 2018). The sloped topography, removal of surface soils during terrace preparation and routine land preparation activities are main reasons for the 
removal of fine clay particles from vegetable cultivated lands in the catchment which is further explained by significantly higher sand contents both in the surface and subsurface soils. Similar sand and clay contents in tea and forest soils revealed a little impact of soil erosion. We observed a good ground cover on sampled tea lands and proper soil conservation measures that would lead to less soil erosion.

Results showed that the SOC content was significantly affected by various land use types $(\mathrm{P}<0.05)$. Forest $(2.4 \%)$ land use had the highest amount of SOC followed by vegetable $(2.1 \%)$ and tea $(1.7 \%)$ in surface. This is obviously credited to the addition of plant residues on the surface of forest soils and low disturbances. However, in comparison to forest land SOC content of vegetable land did not show a significant difference. Long term continuous application of organic manure could be attributed to the higher SOC reserve despite the continuous disturbance to the surface soil by tillage practices. The lowest SOC content was observed in tea plantation. Despite the heavy application of organic manure, vegetable lands showed the lowest SOC levels in the subsurface. This results showed that the routine application of manure has only increased the SOC levels in surface soils. Comparable SOC contents were observed in subsurface soils of forest and tea land uses. This indicated a little disturbance to the subsurface SOC pool by tea cultivation.

Table 2. Correlation coefficients between SOC stocks and topographic factors in surface and subsurface soils

\begin{tabular}{lcccc}
\hline Depth & Elevation (m) & Slope & SPI & WI \\
\hline $0-30 \mathrm{~cm}$ & -0.13 & 0.045 & 0.035 & 0.09 \\
$30-60 \mathrm{~cm}$ & 0.149 & 0.055 & 0.135 & 0.146 \\
\hline
\end{tabular}

Table 3. SOC stocks in relation to land use in surface and subsurface layers

\begin{tabular}{|c|c|c|c|c|c|c|c|}
\hline $\begin{array}{l}\text { SOC Stocks } \\
(\mathrm{Mg} / \mathrm{ha})\end{array}$ & Min & $\operatorname{Max}$ & Mean & $\mathrm{SE}$ & $\mathrm{CV}$ & Skewness & Kurtosis \\
\hline \multicolumn{8}{|c|}{ Surface $(0-30 \mathrm{~cm})$} \\
\hline Forest & 12.5 & 105.8 & $71.8^{a}$ & 5.6 & 36.8 & -1.01 & 0.19 \\
\hline Vegetable & 35.1 & 97.8 & $61.8^{a}$ & 2.3 & 24.6 & 0.08 & -0.57 \\
\hline Tea & 18.0 & 98.8 & $50.7^{b}$ & 3.3 & 42.6 & 0.65 & -0.41 \\
\hline \multicolumn{8}{|c|}{ Subsurface $(30-60 \mathrm{~cm})$} \\
\hline Forest & 39.9 & 88.6 & $69.2^{\mathrm{a}}$ & 2.6 & 18.3 & -0.64 & 0.11 \\
\hline Vegetable & 13.2 & 108.2 & $57.9^{b}$ & 2.8 & 31.6 & -0.02 & 0.73 \\
\hline Tea & 24.1 & 100.9 & $65.6^{b}$ & 2.3 & 23.3 & -0.67 & 1.03 \\
\hline
\end{tabular}

$\mathrm{CV}=$ coefficient of variation, $\mathrm{SE}=$ standard error. Mean values of SOC stocks within each depth followed by different letters are significantly different from each other at $p<0.05$.

Effect of topographic factors on SOC stocks at sub-catchment scale

The observed Pearson's correlation coefficients between the SOC stocks and the topographic variables namely the elevation, slope, SPI and the WI are presented in Table 2. None of the correlations were significant at $\mathrm{p}<0.05$, indicating that the variability of SOC stock is not affected by the topographic factors. 


\section{Impact of land use on SOC stocks}

The variability of surface and subsurface soil organic carbon stocks in relation to land use are presented in Table 3.

The highest average surface SOC stock was observed in the forest soil $(71.8 \mathrm{Mg} / \mathrm{ha})$, which was followed by vegetable $(61.77 \mathrm{Mg} / \mathrm{ha})$ and tea $(50.7 \mathrm{Mg} / \mathrm{ha})$. Addition of organic matter in the form of leaf litter, longer residue time in soil due to less soil disturbances, subsequent accumulation of higher organic carbon and stabilization within aggregates could be attributed to largest SOC stocks in forest soils (Haynes, 2005). However, the surface SOC stock in forest soil did not show any significant difference compared to that of the vegetable soils. This was partly due to the higher heterogeneity of SOC stock in forest lands $(\mathrm{CV}=36.8 \%)$ in comparison to the vegetable fields $(\mathrm{CV}=24.6 \%)$. Surface application of organic matter such as poultry manure to vegetable lands is a common practice in the upcountry wet zone. This could have largely attributed for the accumulation of organic carbon in vegetable soils though the soil texture reveled a considerable soil erosion. Greater C storage in comparatively lower clay containing vegetable soils further highlight the consistent external input of $\mathrm{C}$ to the soil in vegetable lands. Tea grown soils showed the lowest SOC stock at the surface soil $(\mathrm{p}<0.05)$. Tea grown soils are subjected to soil erosion than that of forest and also application of organic manure is not a common management practice in tea cultivation. The application of organic manure is rarely practice in tea cultivation. Further disturbance caused by anthropogenic activities such as removal of leaves, pruning, weed control could reduce capacity of $\mathrm{C}$ sequestration in tea lands. These reasons could have led to lowest SOC stock observed in tea soils in the surface layer.

Forest (69.2 Mg/ha) soil showed a significantly larger subsurface SOC stock $(\mathrm{p}<0.05)$ than those of tea $(65.6 \mathrm{Mg} / \mathrm{ha})$ and vegetable $(57.9 \mathrm{Mg} / \mathrm{ha})$. The mean SOC stock gradually decreased with soil depth in vegetable and forest land use. Interestingly a larger subsurface SOC stock was observed in tea land use. This further justified the depletion of SOC stock in the surface soil of tea. The subsurface store of SOC could be attributed to translocation of organic matter from surface soil and transport of clay-bound organic matter, plant roots and root exudates, dissolved organic matter and bioturbation (Rumpel and Kogel-Knabner., 2011).

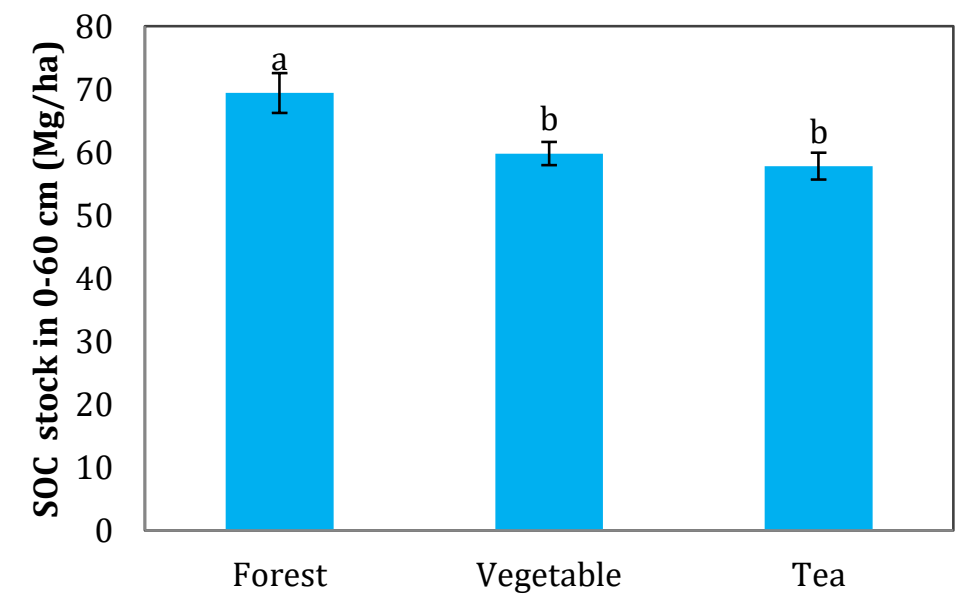

Figure 2. Total SOC stocks in 0-60 cm 
The soils under forest $(69.4 \mathrm{Mg} / \mathrm{ha})$ had significantly highest SOC stock in $0-60 \mathrm{~cm}$ depth than vegetable $(59.8 \mathrm{Mg} / \mathrm{ha})$ and tea $(57.8 \mathrm{Mg} / \mathrm{ha})$ land uses (Figure 2). Soil organic carbon stocks in vegetable and tea lands were $13.8 \%$ and $16.8 \%$ lower as compared to soils under forest. These findings are in agreement with those of Geraei et al. (2016), who observed $36 \%$ depletion in SOC after the conversion of forest to agriculture lands and attributed the loss to rapid mineralization of SOC resulting from intensive tillage. Conversion of forest lands to agriculture has been claimed to damage the soil structure and enhance mineralization of organic matter. Damaged soil structure exposes organic matter which is no longer physically protected by the aggregates from microbial decomposition (Haynes, 2005; Islam and Weil, 2000).

\section{CONCLUSION}

This study concludes that the topographical factors (elevation, slope, SPI and WI) have no significant influence on variation of SOC stocks in the studied sub catchment area. The land use type is a key determinant of the spatial heterogeneity of SOC and forests have the greater ability of sequestering $\mathrm{C}$ compared to tea and vegetable land uses. Conversion of forest land in to agriculture may exert a potential threat of reducing SOC stocks by $13.8 \%$ and $16.8 \%$ for vegetable and tea cultivation, respectively.

\section{AKNOWLEDGEMENT}

Financial assistance from Sri Lanka Council for Agricultural Research Policy (Grant No NARP/16/UP/AG/02) is acknowledged for the financial support.

\section{REFERENCES}

Batjes, N. H., and Sombroek, W. G. (1997). Possibilities for carbon sequestration in tropical and subtropical soils. Global Change Biology, 3(2), 161-173.

Gee, W.G and Or, D. (2002). Particle size analysis. pp. 151-184. In: Jacob, H. Dane, Clarke Topp G. and Warren A. Dick, (Ed.). Methods of Soil Analysis, Part 4: Physical Methods. Soil Science Society of America, Inc. Madison, WI.

Geraei, D. S., Hojati, S., Landi, A., \& Cano, A. F. (2016). Total and labile forms of soil organic carbon as affected by land use change in southwestern Iran. Geoderma regional, 7(1), 29-37.

Haynes, R. J. (2005). Labile organic matter fractions as central components of the quality of agricultural soils: An overview. Advances in agronomy, 85, 221-268.

Islam, K. R. and Weil, R. R. (2000). Land use effects on soil quality in a tropical forest ecosystem of Bangladesh. Agriculture, Ecosystems \& Environment, 79(1), 9-16.

Jayasekara, M. J. P. T. M. and Kadupitiya, H. K. (2018).Mapping of soil erosion hazard zones of Sri Lanka. Tropical Agricultural Research, 29(2), 135-146.

Jenson, S. K. and Domingue, J. O. (1988). Extracting topographic structure from digital elevation data for geographic information system analysis. Photogrammetric engineering and remote sensing, 54(11), 1593-1600.

Mapa, R.B., Somasiri, S. and Dassanayake, A.R. (2009). Soils of the Dry Zone of Sri Lanka. Morphology, Characterization and Classification. Special Publication No. 7.Soil 
Science Society of Sri Lanka. Survodaya Vishva Lekha, Colombo, Sri Lanka. pp. 249.

Minasny, B., Malone, B. P., McBratney, A. B., Angers, D. A., Arrouays, D., Chambers, A., Chaplot, V., Chen, Z.S., Cheng, K., Das, B.S and Field, D. J. (2017). Soil carbon 4 per mille. Geoderma, 292, 59-86.

Moore, I.D., G.J. Burch, and D.H. Mackenzie. (1988). Topographic effects on the distribution of surface soil water and the location of ephemeral gullies. Transactions of ASAE 31:1383-1385.

Mulat, Y., Kibret, K., Bedadi, B. and Mohammed, M. (2018). Soil organic carbon stock under different land use types in Kersa Sub Watershed, Eastern Ethiopia. Afr J Agric Res, 13, 1248-1256.

Nelson, D. W., \& Sommers, L. E. (1996). Total carbon, organic carbon, and organic matter. Methods of soil analysis part 3chemical methods, (methodsofsoilan3), 9611010.
Rumpel, C., and Kögel-Knabner, I. (2011). Deep soil organic matter a key but poorly understood component of terrestrial C cycle. Plant and soil, 338(1-2), 143-158.

Watson, R., Noble, I., Bolin, B. and 32 coauthors (2000). Summary for policymakers: land-use, land-use change and forestry. In: A special report of the Intergovernmental Panel on Climate Change. Cambridge University Press.

Wilson, J.P., and J.C. Gallant. (2000). Digital terrain analysis, p. 1-27, In J. P. Wilson and J. C. Gallant, (Ed). Terrain analysis: principles and applications. John Wiley \& Sons, Inc. NY. 